\title{
Status of Soil Microbial Population, Enzymatic Activity and Biomass of Selected Natural, Secondary and Rehabilitated Forests
}

\author{
${ }^{2,3}$ Daljit Singh, K.S., ${ }^{1,3}$ A. Arifin, ${ }^{2,4}$ O. Radziah, ${ }^{2}$ J. Shamshuddin, ${ }^{1,3}$ A.H. Hazandy, \\ ${ }^{3}$ N.M. Majid, ${ }^{1}$ J. Aiza-Shaliha, ${ }^{1}$ T.X. Rui and ${ }^{1}$ S.R. Keeren \\ ${ }^{1}$ Department of Forest Management, Faculty of Forestry, \\ ${ }^{2}$ Department of Land Management, Faculty of Agriculture, \\ ${ }^{3}$ Laboratory of Sustainable Bioresource Management, \\ Institute of Tropical Forestry and Forest Products, \\ ${ }^{4}$ Laboratory of Food Crops and Floriculture, Institute of Tropical Agriculture, \\ Universiti Putra Malaysia, 43400 UPM Serdang, Selangor, Malaysia
}

Received 2013-04-13, Revised 2013-07-03; Accepted 2013-07-25

\begin{abstract}
Substantial clearance of forests and conversion of forest into various land use types contribute to deterioration of soil fertility and associated nutrients loss. Soils from natural and rehabilitated forest in Chikus Forest Reserve and also enrichment planting forest and secondary forest of Tapah Hill Forest Reserve, Perak, Malaysia were selected in order to assess the influence of land use change on biological properties. This study was carried out to provide fundamental information on soil biological properties and also to compare the differences between natural forest, mono-rehabilitated forest, mixed planting forest and natural regenerated forest (secondary forest). Six subplots $(20 \times 20 \mathrm{~m})$ were established at each study plot and soil samples were collected at the depths of $0-15 \mathrm{~cm}$ (topsoil) and $15-30 \mathrm{~cm}$ (subsoil). Soil microbial population was determined using spread-plate technique. Fluorescein Diacetate (FDA) hydrolysis was used to assess the amount of microbial enzymatic activity for each forest plot. Soil Microbial Biomass C (MBC) and N (MBN) were extracted using chloroform fumigation extraction technique and the amount of $\mathrm{MBC}$ was determined by dichromate digestion, while MBN via Kjeldahl digestion technique. Soil acidity was determined by $\mathrm{pH}$ meter and moisture content was elucidated using gravimetric method. The levels of microbial population of bacterial and fungal at natural significantly exceeded the corresponding values of rehabilitated and secondary forest. However, microbial population is much higher in rehabilitated forest of Tapah Hill compared to that of secondary forest and also Chikus Forest Reserve planted forest which proves that rehabilitation activities do help increase the level of microbial community in the soils. Longer period of time after planting as in enrichment planting compared to mono planting of $S$. leprosula plantation showed that restoring and recovery of the planted forest needed time. Deforestation activities decrease soil biological activities; however, proper forest management and rehabilitation activities are able to restore the condition of degraded forest land to its original state.
\end{abstract}

Keywords: Natural Forest, Rehabilitated Forest, Enrichment Planting, Microbial Enzymatic Activity, Soil Microbial Biomass

Corresponding Author: Arifin, A., Laboratory of Sustainable Bioresource Management, Institute of Tropical Forestry and Forest Products, Universiti Putra Malaysia, 43400 UPM Serdang, Selangor, Malaysia 


\section{INTRODUCTION}

Malaysia is one of the mega-biodiversity countries in the world known for its tropical rainforest (Arifin et al., 2008; Hamzah et al., 2009; Zaidi et al., 2010; Karam et al., 2011 ; 2012). Tropical rainforest is a system that is in constant flux where it is continuously restructuring itself (Gonzalez-Iturbe et al., 2002; Aquilar-Amuchastequi and Henebry, 2007). It acts as animportant regulator of carbon cycle, biological conservation, woody and nonwoody production, soil and water conservation and acts as protection from flood, drought and erosion Food and Agriculture Organization, 1995 (Karam et al., 2012). However, tropical forest also being the subject of overlogging and deforestation activities due to the demand of high timber quality. Many deforested areasare left without proper forest treatment and silvilculture, leading to massive soil erosion and degradation. To overcome this problem, efforts to rehabilitate plantations on degraded forestland have been carried out in order to overcome the problem of over exploitation of tropical rainforest product and to restore soil fertility.

Arifin et al. (2008) stated that in the past forest rehabilitation activity in Malaysia was started with natural regeneration approach. It was later converted into artificial regeneration planting of exotic species like Acacia mangium where it can grow and adapt faster on degraded forest land (Arifin et al., 2008; Karam et al., 2012). Besides, indigenous and exotic tree species which exhibit superior survival and growth characteristics and can grow on poor nutrient soils are chosen. This is because these tree species might be able to increase the soil fertility (Otsamo et al., 1996; Otsamo, 1998; Akbar et al., 2010).

Forest which is left for natural regeneration without any forest treatment is known as secondary forest. Akbar et al. (2010) and Karam et al. (2011) defined secondary forest as the forest that regenerate after improper and misused years. Karam et al. (2012) carried out studies on the biological properties of soils between secondary forest and enrichment planting in Tapah Hill Forest Reserve, Perak found that the secondary forest used to be forest that wasover-exploited for its woody and non woody products. The majority of secondary forest tree species are thought to be fast growing and light demanding species such as Macaranga spp. as compared to primary forest species because light intensity is higher than primary forest (Saga et al., 2010; Singh et al., 2012; Arifin et al., 2008).
One of the artificial planting techniques utilized for forest rehabilitation activity in Malaysia is enrichment planting. Montagnini et al. (1997) stated that introduction of valuable and high quality tree species to degraded forest land without elimination of other existing valuable individual trees is known as enrichment planting. Johnson and Lapadat (2002) described enrichment planting as an artificial regeneration technique designed to improve the proportion of a desired species. Costa et al. (2000) concluded that enrichment planting is more effective in lowering negative impacts on soil quality compared to monoculture technique because it results in less susceptibility to pest and diseases, higher biodiversity, better water conservation and less soil erosion.

Multi-storied forest management is a technique of forest rehabilitation in which high quality timber trees are employed to create two or more layers of canopies (Arifin et al., 2008; Karam et al., 2012). The upper canopies are secondary forest, while the lower canopy consists of the planted or introduced dipterocarps trees species. In Malaysia, Multi-Storied Forest Management Project was carried out from 1991 to 1999. Multi-storied planting technique is a method of replanting trees by using fast growing trees to act as a canopy sheltering shade tolerant tree species. The Forestry Department Peninsular Malaysia (FDPM, 2003) stated that multistoried forest management has gained significant attention as an ideal forest management technique for conserving biodiversity, preserving the environment and producing timber. Chikus and Bukit Kinta Forest Reserves in Perak, Malaysia, have been subjected to this multi-storied planting technique where Acacia mangium and indigenous high quality timber species including Shorea and Hopea spp. were planted during the early stage of the project.

Forest soil is home to bulk of forest biodiversity and its importance cannot be neglected (Arpin et al., 1998; Caravaca et al., 2002; Decaens et al., 2006). It is a heterogeneous and structured environment dominated by a solid phase and wherein microbial life exists in discrete microhabitats, physical, chemical and biological characteristics of which differ in both time and space (Aiko et al., 2000; Beylich et al., 2010; Susyan et al., 2011). Gregorich et al. (1998) investigated the biological attributes of soil which include living organisms and material derived from living organisms namely plants, animals and microbes, ranging in various size and function. Dinesh et al. (2003) reported that soil possessed the ability to supply nutrients to plants and have the potential capacity to perform as essential key of ecological function where the soil structure can be easily 
disturbed when affected by disturbances, physically, chemically or biologically.

Soil microorganisms are the driving force for the nutrient cycling processes in the soils because it is able to carry and transfer this substrate through biochemical process (Lima et al., 1996; Jordan et al., 1999; Garau et al., 2007). Barabasz et al. (2002) claimed that soil microorganisms play a crucial role in the functional process of the entire ecosystems since they can exert essential effects on the dynamics of multidirectional microbiological processes.

Soil microbial enzymatic activity is central to the soil biological processes as its associated with organic matter breakdown and nutrient cycling which is being mediated by soil microorganism (Karam et al., 2012). Research on soil enzymes provides insights into biogeochemical cycling of carbon and other nutrients and on microbial community functions in space and time. Moussa and Abdel-Aziz (2008) reported that high levels of microbial activities are fundamental in maintaining soil quality. Thus, soil microbial activities can be considered to have a direct influence on ecosystem stability and fertility.

Microbial biomass is defined as the living microbial component of the soil consisting largely of pools of bacteria and fungi (Gregorich et al., 1998). Microbial biomass is considered to serve as the primary catalyst of bio-geochemically processedproduct as well as energy and nutrient reservoir in soil. Soil microbial biomass can also react quickly to the changes occurring in nutrient cycling, humidity, temperature, organic matter levels and soil cation availability (Peacock et al., 2001). Insam et al. (1991) studied that soil Microbial Biomass Carbon (MBC) and Nitrogen (MBN) are the recycling and store pools of soil $\mathrm{C}$ and $\mathrm{N}$. Viable soil microbial biomass is integral for aggregate formation, both a source and sink of available nutrients for plants and regulating ecosystems process such as decomposition, energy flow and trace gas fluxes in soil (Peacock et al., 2001; Haubensak et al., 2002; Mendham et al., 2002).

Evaluation on soil fertility and quality has been made every year at different forest types; however, there islack of information on soil biological properties as many research focus more on physical and chemical aspects of the forest soil properties. Furthermore, data on the effects of rehabilitating forest on soil fertility focusing on establishment of enrichment planting are also lacking because many individual and organization are more interested on the tree growth performance without knowing that the success of forest rehabilitation are based on the ability on the soil to provide adequate supply of nutrients for the plants to grow well. The objectives of the current research studies were: (1) to provide fundamental information on soil biological properties; and (2) to determine the differences in biological properties level at natural, secondary and rehabilitated and enrichment planting forests atChikus and Tapah Hill Forest Reserves, Perak, Malaysia.

\section{MATERIALS AND METHODS}

\subsection{Description of the Study Sites}

Ths study was carried out in a natural forest ( $\mathrm{N}$ $04.10076^{\circ} \mathrm{C} \mathrm{E} 101.19411^{\circ}, \pm 28 \mathrm{~m}$ a.s.l) and an 18 -yearold stand of Shorea leprosula (N 04.09197 ${ }^{\circ}$ E $101.19499^{\circ}, \pm 28 \mathrm{~m}$ a.s.l) in Chikus Forest Reserves, Perak, Malaysia. Planted forest (N 04.179394 ${ }^{\circ} \mathrm{E} 101.31998^{\circ}, \pm 46$ $\mathrm{m}$ a.s.l) and secondary forest ( $\mathrm{N} 04.17336^{\circ} \mathrm{E} 101.31974^{\circ}$, $\pm 32 \mathrm{~m}$ a.s.l) in Tapah Forest Reserves, Perak were also selected as study sites. Sampling was done on December 10th 2010 to January 14th, 2013.

In Chikus Forest Reserve, the area has an average annual precipitation of $3223 \mathrm{~mm}$ and a mean temperature of $27.7^{\circ} \mathrm{C}$. The S. leprosula was planted in 1992 through collaborative effort of the MultiStoried Forest Management System involving the Forestry Department Peninsular Malaysia, Perak State Forestry Department and Japan International Cooperation Agency (JICA). The planting distance for each tree was $10 \times 3 \mathrm{~m}$.

As for planted forest atTapah Hill Forest Reserve, the tree was planted in 1968 using enrichment planting technique where new tree species were planted without distrupting the growth of other existing trees. The adjacent secondary forest was left idle without any forest silviculture treatment to allow natural regeneration. $S$. leprosula, S. parvifolia, S. bracteolata and S. macroptera were the main species of Dipterocarpaceae planted in the compartment 13 of the enrichment planting plots. The distance between each tree was also $10 \times 3 \mathrm{~m}$.

\subsection{Sampling Design and Soil Sampling}

This study used a completely randomized design. Six subplots were demarcated in each plot in order to serve as replicates. Six soil samples were randomly collected at the depths of $0-15 \mathrm{~cm}$ and $15-30 \mathrm{~cm}$ in each subplot. The samples were then mixed together to form a composite sample for each soil depth range based on subplot. The composite sample collected for biological properties analyses was kept in a UV-sterilized polyethylene bags at $0-4^{\circ} \mathrm{C}$ prior to immediate analyses. 
Another part of the soil composite samples were airdried for $48 \mathrm{~h}$ and kept in polyethylene bags for physical and chemical properties analyses.

\subsection{Soil Analyses}

A spread-plate technique was used to estimate the microbial population (Sleytr et al., 2007; Cycon and Piotrowska-Seget, 2009). Nutrient agar was employed for bacterial culture where dilution factor of $10^{-2}, 10^{-3}$ and $10^{-4}$ were found to be suitable for colony calculation after few pilot tests were carried out to standardize the dilution factor for every population count. The Fluorescen Diacetate (FDA) hydrolysis assay illustrated by Sanchez-Monedero et al. (2008) and Gagnon et al. (2007) was used to evaluate microbial enzymatic activity. Soil Microbial Biomass C (MBC) and N (MBN) were extracted using rapid chloroform fumigation extraction procedure as described by Witt et al. (2000). Soil MBC was analysed by wet dichromate oxidation (Vasquez-Murrieta et al., 2007) and calculation for biomass $\mathrm{C}$ was as follow (Equation 1):

$$
\mathrm{MBC}=\left(\mathrm{C}_{\text {fumigated }}-\mathrm{C}_{\mathrm{un}-\text { fumigated }}\right) / \mathrm{kEC}
$$

The chloroform-labile $\mathrm{C}$ pool was calculated as the difference between samples of fumigated and fumigated which is proportional to $\mathrm{MBC}$, where $\mathrm{kEC}$ is soil specifically estimated as 0.38 (Vance et al., 1987).

Soil MBN was determined using the Kjeldahl digestion and distillation technique. The calculation for biomass $\mathrm{N}$ was as follows (Equation 2):

$$
\mathrm{MBN}=\left(\mathrm{N}_{\text {fumigated }}-\mathrm{N}_{\text {un-fumigated }}\right) / \mathrm{kEN}
$$

The chloroform-labile $\mathrm{N}$ pool was calculated as the difference between samples of unfumigated and fumigated $\mathrm{N}$ which is proportional to $\mathrm{MBN}$, where $\mathrm{kEN}$ is soil specifically estimated at 0.54 (Brookes et al., 1985).

Bulk density was determined using disturbed soil technique, while gravimetric method was used for soil moisture content determination (Gupta, 2009). Soil acidity was extracted in 1:5 soil to water ratio and the degree of active hydrogen ions $\left(\mathrm{H}^{+}\right)$was read using glass-electrode meter (Akbar et al., 2010; Saga et al., 2010; Karam et al., 2012).

\subsection{Statistical Analyses}

A one way Analysis of Variance (ANOVA) and post hoc test of Duncan Multiple Range Test (DMRT) was used to compare the differences between mean values for each parameter analysed including microbial population, microbial enzymatic activity, microbial biomass $\mathrm{C}$, microbial biomass $\mathrm{N}$ and selected soil physic-chemical properties analysed. SPSS version 16.00 was used for the data analyses and arrangement.

\section{RESULTS}

\subsection{Acidity, Moisture Content and Biological Properties of the Soils at Selected Forests in Chikus and Tapah Hill Forest Reserves}

Soil acidity and moisture content values for each natural, planted $S$. leprosula, secondary forest and enrichment planting plot are presented in Table 1. All of the forest plots exhibited acidic soil reactioneither in the topsoil or subsoil. The $\mathrm{pH}$ of the forests studied ranged between 4.00 and 4.63 with values lower in the topsoil. This is because of the presence of more organic matter in the topsoil; organic matter contains organic acids. Natural forest of Chikus Forest Reserves showed the highest amount of moisture content, followed by enrichment planting plot. The moisture content for each forest plot soil decreased from topsoil to the subsoil.

Table 2 shows the results of selected soil biological properties analysed of selected forests studied. Natural forest had the higher amount of microbial population compared to the other forest plots. The topsoil in secondary forest and enrichment planting of Tapah Hill Forest Reserves showed the lowest significant differences in total mean of bacteria population.

Table 1. Soil $\mathrm{pH}$ and moisture content in selected forests in Chikus and Tapah Hill Forest Reserves

\begin{tabular}{lll}
\hline Plot & $\mathrm{pH}$ & Moisture content (\%) \\
\hline Topsoil $(0-15 \mathrm{~cm})$ & & \\
Natural forest & $4.21 \pm 0.09^{\mathrm{a}}$ & $52.83^{\mathrm{a}}$ \\
Planted S. leprosula & $4.24 \pm 0.09^{\mathrm{a}}$ & $19.50^{\mathrm{c}}$ \\
Secondary forest & $4.26 \pm 0.03^{\mathrm{a}}$ & $20.50^{\mathrm{c}}$ \\
Enrichment planting & $4.00 \pm 0.01^{\mathrm{a}}$ & $26.33^{\mathrm{b}}$ \\
Subsoil (15-30 cm) & & \\
Natural forest & $4.63 \pm 0.01^{\mathrm{a}}$ & $50.50^{\mathrm{a}}$ \\
Planted S. leprosula & $4.54 \pm 0.03^{\mathrm{b}}$ & $17.67^{\mathrm{b}}$ \\
Secondary forest & $4.30 \pm 0.02^{\mathrm{c}}$ & $19.17^{\mathrm{b}}$ \\
Enrichment planting & $4.23 \pm 0.03^{\mathrm{d}}$ & $23.33^{\mathrm{b}}$ \\
\hline Note: Different &
\end{tabular}

Note: Different letters within row indicate significant differences between means of the same soil depths at selected forests in Chikus and Tapah Hill Forest Reserves 
Daljit Singh, K.S. et al. / American Journal of Environmental Science 9 (4): 301-309, 2013

Table 2. Selected soil biological properties of selected forests in chikus and tapah hill forest reserves

\begin{tabular}{|c|c|c|c|c|}
\hline Parameters & Natural forest & Planted S. lerosula & Secondary forest & Enrichment planting \\
\hline \multicolumn{5}{|l|}{ Topsoil $(0-15 \mathrm{~cm})$} \\
\hline Bacterial count $\left(\log _{10} \mathrm{~g}^{-1}\right.$ soil $)$ & $5.37 \pm 0.10^{\mathrm{a}}$ & $4.91 \pm 0.08^{\mathrm{b}}$ & $4.04 \pm 0.10^{\mathrm{c}}$ & $4.21 \pm 0.07^{\mathrm{c}}$ \\
\hline Fungal count $\left(\log _{10} \mathrm{~g}^{-1}\right.$ soil) & $4.37 \pm 0.05^{\mathrm{a}}$ & $4.06 \pm 0.03^{\mathrm{bc}}$ & $3.99 \pm 0.06^{\mathrm{c}}$ & $4.16 \pm 0.04^{b}$ \\
\hline Enzymatic activity $\left(\mu \mathrm{g} \mathrm{g}^{-1} 0.5 \mathrm{~h}^{-1}\right)$ & $58.54 \pm 1.19^{\mathrm{ab}}$ & $52.83 \pm 4.15^{\mathrm{b}}$ & $54.92 \pm 5.24^{\mathrm{b}}$ & $64.34 \pm 1.72^{\mathrm{a}}$ \\
\hline Biomass C ( $\mu \mathrm{g} \mathrm{g}^{-1}$ soil) & $198.08 \pm 46.01^{\mathrm{a}}$ & $118.68 \pm 28.00^{\mathrm{a}}$ & $133.44 \pm 70.99^{\mathrm{a}}$ & $134.90 \pm 30.45^{\mathrm{a}}$ \\
\hline Biomass $\mathrm{N}\left(\mu \mathrm{g} \mathrm{g}^{-1}\right.$ soil $)$ & $149.22 \pm 19.67^{\mathrm{b}}$ & $37.17 \pm 4.48^{\mathrm{c}}$ & $161.64 \pm 17.62^{b}$ & $239.04 \pm 7.99^{\mathrm{a}}$ \\
\hline \multicolumn{5}{|l|}{ Subsoil $(15-30 \mathrm{~cm})$} \\
\hline Bacterial count $\left(\log _{10} \mathrm{~g}^{-1}\right.$ soil $)$ & $4.52 \pm 0.07^{\mathrm{a}}$ & $4.09 \pm 0.04^{\mathrm{b}}$ & $3.99 \pm 0.07^{\mathrm{b}}$ & $4.11 \pm 0.12^{\mathrm{b}}$ \\
\hline Fungal count $\left(\log _{10} \mathrm{~g}^{-1}\right.$ soil) & $4.36 \pm 0.07^{\mathrm{a}}$ & $4.09 \pm 0.07^{\mathrm{b}}$ & $2.98 \pm 0.03^{\mathrm{c}}$ & $4.06 \pm 0.05^{\mathrm{b}}$ \\
\hline Enzymatic activity $\left(\mu \mathrm{g} \mathrm{g}^{-1} 0.5 \mathrm{~h}^{-1}\right)$ & $57.67 \pm 1.66^{\mathrm{a}}$ & $51.22 \pm 3.65^{\mathrm{a}}$ & $55.88 \pm 5.53^{\mathrm{a}}$ & $56.76 \pm 2.83^{\mathrm{a}}$ \\
\hline Biomass $\mathrm{C}\left(\mu \mathrm{g}^{-1}\right.$ soil $)$ & $84.99 \pm 25.08^{\mathrm{a}}$ & $74.83 \pm 23.86^{\mathrm{a}}$ & $105.81 \pm 3864^{\mathrm{a}}$ & $164.95 \pm 38.67^{\mathrm{a}}$ \\
\hline Biomass $N\left(\mu \mathrm{g}^{-1}\right.$ soil $)$ & $113.49 \pm 29.05^{\mathrm{ab}}$ & $9.00 \pm 4.12^{\mathrm{c}}$ & $78.48 \pm 11.24^{\mathrm{b}}$ & $134.28 \pm 12.09^{\mathrm{a}}$ \\
\hline
\end{tabular}

Note: Different letters within same row indicate significant differences $(\mathrm{p}<0.05)$ between means of the same soil depths at selected forests in Chikus and Tapah Hill Forest Reserves

In contrast, there were no significant differences detected at subsoil between planted $S$. leprosula forest of Chikus Forest Reserve, enrichment planting and secondary forest plots of Tapah Hill Forest Reserve. Natural forest also possessedhigher fungal count compared to that of the planted forest of $S$. leprosula, secondary forest and enrichment planting plots.Nevertheless, the secondary forest showed the lowest total microbial population of fungi. There is no much difference that could be found in total fungi microbial population in between planted $S$. leprosula and enrichment planting plots.

Besides, topsoil at enrichment planting showed the higher total amount of microbial enzymatic activities compared with natural, rehabilitated and secondary forests. Furthermore, there was no significant difference detected between natural forest and enrichment planting plots and alsobetween planted $S$. leprosula plot and secondary forest. There were no significant differences among four types of forests at subsoil level and the microbial enzymatic rate in subsoil level was generally lower compared to that of the topsoil.

There were no significant differences of MBC observed at Chikus and Tapah Forests Reserves at the same soil depths. The MBN in the soils of enrichment planting plot showed the highest significant difference. There were no significant differences detected forMBN level at natural forest and secondary forest plots. MBN of planted $S$. leprosula plots was relatively low at both soil depths.

\section{DISCUSSION}

High amount of fungi communities in the natural forest is due to the natural forest condition which is undisturbed and contain abundance of organic matter on the ground (Karam et al., 2011; 2012). Organic matter serves as an ideal medium for fungal growth (Beare et al., 1997; Banning et al., 2008). This condition occurs because the natural forest is in equilibrium state and has an abundant plant dead material which is the main source of organic matter in the soils (Kourtev et al., 2002; Bird et al., 2011). Hence, it promotes microbial decomposing activity and increases soil fertility (Meriles et al., 2009; Tang et al., 2011). Besides, the well root growth condition in natural forest stimulates the growth of bacterial and fungal populations by increasing root exudates (Barbhuiya et al., 2004). In addition, high soil moisture in natural forest might affect the amount of root exudation which contributes to increase in microbial population (Paradelo and Barral, 2009; Karam et al., 2011). Nevertheless, decrease in fine root production especially in compacted soil might result in changes in microbial population with fewer fungi and reduced carbohydrates in soil (Xiao et al., 2005).

Microbial enzymatic activity was found to be higher in the topsoil ofthe natural and enrichment planting compared to that of the rehabilitated and secondary forest because natural forest is diverse in vegetation, rich soil nutrients and high in soil litter inputs (Barbhuiya et al., 2004; Karam et al., 2011; 2012). Similarly, the indigenous and exotic species planted in enrichment planting plot contributed to a high accumulation of leaf litter on the forest floor after 42 years. Saswati and Vadakepuram (2010) justified that microbial enzyme activities were significantly correlated with nutrient parameters. Moreover, process of litter decaying has been proven to be increased the enzymatic 
activities (Kourtev et al., 2002; Li et al., 2004). Nevertheless, the respectively low rate of microbial enzymatic activities at planted $S$. leprosula plot and secondary forest might have incurred due to previous logging and cultivation activities (Kobayashi, 2004).

The levels of MBC and MBN at the plantation site showed higher values compared to other three plots, indicating greater microbial activity under the plantation sites. The very low microbial biomass $\mathrm{N}$ at rehabilitated and secondary forest may be described as soil may become compacted through heavy traffic created by logging. Compaction might decrease soil microbial biomass due to lower availability of organic substrates and nutrients, aeration, soil moisture content and oxygen deficiency (Bouwman and Arts, 2000; Hakansson and Lipiec, 2000; Xiao et al., 2005). Nonetheless, some studies show that soil compaction did not affect MBC (Xiao et al., 2005) in both the forest floor and mineral soil. On the other hand, Barbhuiya et al. (2004) investigated abundance of forest floor litter which favoured the growth of microbial biomass $\mathrm{C}$ and $\mathrm{N}$ in the natural forest and enrichment planting plots where it proved that the diversity of the organic substrate production in enrichment planting which improved the quality of soil nutrients, contributing to a high level of microbial biomass in the soils.

\section{CONCLUSION}

Bacterial and fungal population was found to be comparatively high in undisturbed natural forest soil compared to that of the disturbed, deforested, degraded land or converted forest. Natural forest and planted forest inTapah Hill Forest Reserve showed higher microbial enzymatic activity due to high amount of organic matter which serves as suitable medium for soil microorganism growth and decomposition activities to take place. Topsoil contains higher amount of microbial population, enzymatic activity and microbial biomass compared to subsoil because the uppermost layer of the soil is usually concentrated with organic matter and plant roots. Enrichment planting technique is better compared to other techniques in terms of soil biological properties. This is because the variety of species planted in enrichment planted forest gave variety of substrate medium for soil microbial decomposition activities. It is recommended that soil biological properties of rehabilitated and planted forest in tropical regions should be further studied because microbial indices of forest soils subjected to long-term disturbance would provide a valuable insight into the extent of soil deterioration and help enhance management practices and strategies in improving forest soil quality.

\section{ACKNOWLEDGEMENT}

We are thankful to the staff members of Perak South District, Perak Forestry Department, Malaysia and Forestry Department Peninsular Malaysia who allowed and helped us during the research project. Our sincere gratitude is extended to the Ministry of Higher Education of Malaysia who generously gave financial support under Fundamental Research Grant Scheme (FRGS) and Research University Grant Scheme (RUGS) through Universiti Putra Malaysia.

\section{REFERENCES}

Aiko, S., H. Vare and R. Strommer, 2000. Soil microbial activity and biomass in the primary succession of a dry heath forest. Soil Biol. Biochem., 32: 10911100. DOI: 10.1016/S0038-0717(00)00019-5

Akbar, M.H., A.S. Jamaluddin, N.M. Nik, H. Majid and S. Abdul-Hamid et al., 2010. Differences in soil physical and chemical properties of rehabilitated and secondary forests. Am. J. Applied Sci., 7: 12001209. DOI: 10.3844 /ajassp.2010.1200.1209

Aquilar-Amuchastequi, N. and G.M. Henebry, 2007. Assessing sustainability indicators for tropical forests: Spation-temporal heterogeneity, logging intensity and dung beetle communities. Forest Ecol. Manage., 253: 56-67. DOI: 10.1016/j.foreco.2007.07.004

Arifin, A., S. Tanaka, S. Jusop, N.M. Majid andK. Sakurai, 2008. Rehabilitation of degraded tropical rainforest in Peninsular Malaysia with a multistoried plantation technique of indigenous dipterocarp species. J. Forest Environ., 50: 141-152. DOI: 10.3923/ijss.2010.112.130

Arpin, P., J.F. Ponge, A. Faille and P. Blaudin, 1998. Diversity and dynamics of eco-units in the biological reserves of the Fontainebleau Forest (France): Contribution of soil biology to a functional approach. Eur. J. Soil Biol., 34: 167-177. DOI: 10.1016/S1164-5563(00)86659-5

Banning, N.C., C.D. Grant, D.C. Jones and D.V. Murphy, 2008. Recovery of soil organic matter, organic matter turnover and nitrogen cycling in a post-mining forest rehabilitation chronosequence. Soil Biol. Biochem., 40: 2021-2031. DOI: 10.1016/j.soilbio.2008.04.010 
Barabasz, W., D. Albinska, M. Jaskowska and J. Lipiec, 2002. Biological effects of mineral nitrogen fertilization on soil microorganisms. Polish J. Environ. Stud., 11: 193-198.

Barbhuiya, A.R., A. Arunachalam, H.N. Pandey and Aruna, 2004. Dynamics of soil microbial biomass C, $\mathrm{N}$ and $\mathrm{P}$ in disturbed and undisturbed stands of a tropical wet evergreen forest. Eur. J. Biol., 40: 113121. DOI: 10.1016/j.ejsobi.2005.02.003

Beare, M.H., S. Hui, D.C. Coleman and P.F. Hendrix, 1997. Influences of mycelial fungi on soil aggregation and organic matter storage in conventional and no-tillage soils. Applied Soil Ecol., 5: 211-219. DOI: 10.1016/S0929-1393(96)00142-4

Beylich, A., H.R.Oberholzer, S. Schrader, H. Höper and B.M.Wilke, 2010. Evaluation of soil compaction effects on soil biota and soil biological process in soils. Soil Tillage Res., 109: 133-143. DOI: 10.1016.j.still.2010.05.010

Bird, J.A., D.J. Herman and M.K. Firestone, 2011. Rhizosphere priming of soil organic matter by bacterial groups in a grassland soil. Soil Biol. Biochem., 43: $718-725$. 10.1016/j.soilbio.2010.08.010

Bouwman, L.A. and W.B.M. Arts, 2000. Effects of soil compaction on the relationships between nematodes, grass production and soil physical properties. Applied Soil Ecol., 14: 213-222. DOI: 10.1016/S0929-1393(00)00055-X

Brookes, P.C., A. Landman, G. Pruden and D.S. Jenkinson, 1985. Chloroform fumigation and the release of soil nitrogen: A rapid direct extraction method to measure microbial biomass nitrogen in soil. Soil Biol. Biochem., 17: 837-842. DOI: 10.1016/0038-0717(85)90144-0

Caravaca, F., J.M. Barea, D. Figueroa and A. Roldan, 2002. Assessing the effectiveness of mycorrhizal inoculation and soil compost addition for enhancing reafforestation with Olea europaea subsp. sylvestris through changes in soil biological and physical parameters. Applied Soil Ecol., 20: 107-118. DOI: 10.1016/S0929-1393(02)00015-X

Costa, P.M., M. Stuart, M. Pinard and G. Phillips, 2000. Elements of a certification system for forestry-based carbon offset projects. Mitigat. Adaptat. Strateg. Global Change, 5: 39-50. DOI: 10.1023/A:1009656501414

Cycon, M. and Z. Piotrowska-Seget, 2009. Changes in bacterial diversity and community structure following pesticides addition to soil estimated by cultivation technique. Ecotoxicology, 18: 632-642. DOI: $10.1007 / \mathrm{s} 10646-009-0321-6$
Decaens, T., J.J. Jimenez, G.J. Measey and P. Lavelle, 2006. The values of soil animals for conservation biology. Eur. J. Soil Biol., 42: S23-S38. DOI: 10.1016/j.ejsobi.2006.07.001

Dinesh, R., S.C. Ghoshal, A.N., Ganeshamurthy and D. Chanchal, 2003. Changes in soil microbial indices and their relationships following deforestation and cultivation in wet tropical forests. Applied Soil Ecol., 24: 17-26. DOI: 10.1016/S09291393(03)00070-2

FDPM, 2003. Forest Plantation for the Future-A Record of the Multi-Storied Forest Management Project in Malaysia and the Small Scale Fast-Growing Forest Plantation Project in Malaysia.

Gagnon, V., F. Chazarenc, Y. Comeau and J. Brisson, 2007. Influence of macrophyte species on microbial density and activity in constructed wetlands. Water Sci. Technol., 56: 249-254. PMID: 17802862

Garau, G., P. Castaldi, L. Santona, P. Deiana and P. Melis, 2007. Influence of red mud, zeolite and lime on heavy metal immobilization, culturable, heterotrophic microbial populations and enzyme activities in a contaminated soil. Geoderma, 142: 4727. DOI: 10.1016/j.geoderma.2007.07.011

Gonzalez-Iturbe, J.A., I. Olmsted and F. Tun-Dzul, 2002. Tropical dry forest recovery after long term Henequen (sisal, Agave fourcroydes Lem.) plantation in northern Yucatan, Mexico. Forest Ecol. Manage., 167: 67-82. DOI: 10.1016/S03781127(01)00689-2

Gregorich, E.G., K.J. Greer, D.W. Anderson and B.C. Liang, 1998. Carbon distribution and losses: Erosion and deposition effects. Soil Tillage Res., 47: 291302. DOI: 10.1016/S0167-1987(98)00117-2

Gupta, P.K., 2009. Soil, Plant, Water and Fertilizer Analysis. 2nd Edn., Agrobios, Jodhpur, ISBN-10: 8177543067, pp: 366.

Hakansson, I. and J. Lipiec, 2000. A review of the usefulness of relative bulk density values in studies of soil structure and compaction. Soil Tillage Res., 53: 71-85. DOI: 10.1016/S0167-1987(99)00095-1

Hamzah, M.Z., A. Arifin, A.K. Zaidey, A.N. Azirim and I. Zahari et al., 2009. Characterizing soil nutrient status and growth performance of planted dipterocarp and non dipterocarp species on degraded forest land in Peninsular Malaysia. J. Applied Sci., 9: 4215-4223. DOI: 10.3923/ajas.2009.4215.4223 
Haubensak, K.A., S.C. Hart and J.M. Stark, 2002. Influences of chloroform exposure time and soil water content on $\mathrm{C}$ and $\mathrm{N}$ release in forest soils. Soil Biol. Biochem., 34: 1549-1562. DOI: 10.1016/s0038-0717(02)00124-4

Insam, H., C.C. Mitchell and J.F. Dormaar, 1991. Relationship of soil microbial biomass and activity with fertilization practice and crop yield of three Ultisols. Soil Biol. Biochem., 23: 459-464. DOI: 10.1016/0038-0717(91)90010-H

Johnson, G.L. and R. Lapadat, 2002. Mitogen-Activated Protein Kinase Pathways Mediated by ERK, JNK and p38 Protein Kinases. Science, 298: 1911-1912. DOI: $10.1126 /$ science. 1072682

Jordan, D., F. Li, F.P. Jr, E.C. Berry and V.C. Hubbard et al., 1999. The effects of forest practices on earthworm populations and soil microbial biomass in a hardwood forest in Missouri. Applied Soil Ecol., 13: 31-38. DOI: 10.1016/S09291393(99)00017-7

Karam, D.S., A. Abdu, O. Radziah, J. Shamshuddin and H. Abdul-Hamid et al., 2011. Assessing soil biological properties of natural and planted forests in the Malaysian tropical lowland dipterocarp forest. Am. J. Applied Sci., 8: 854-859. DOI: 10.3844/ajassp.2011.854.859

Karam, D.S., A. Arifin, O. Radziah, J. Shamshuddin and N.M. Majid et al., 2012. Impact of long-term forest enrichment planting on the biological status of soil in a deforested dipterocarp forest in Perak, Malaysia. Sci. World J. DOI: $10.1100 / 2012 / 641346$

Kobayashi, S., 2004. Landscape rehabilitation of degraded tropical forest ecosystems: Case study of the CIFOR/Japan project in Indonesia and Peru. Forest Ecol. Manage., 201: 13-22. DOI: 10.1016/j.foreco.2004.06.009

Kourtev, P.S., J.G. Ehrenfeld and W.Z. Huang, 2002. Enzyme activities during litter decomposition of two exotic and two native plant species in hard wood forests of New Jersey. Soil Biol. Biochem., 34: $1207-1218$. DOI: $10.1016 / \mathrm{S} 0038-$ 0717(02)00057-3

Li, Q., H.L. Allen and A.G. Wollum, 2004. Microbial biomass and bacterial functional diversity in forest soils: Effects of organic matter removal, compaction and vegetation control. Soil Biol. Biochem., 36: 571-579. DOI: 10.1016.j.soilbio.2003.12.001
Lima, J.A., E. Nahas and A.C. Gomes, 1996. Microbial populations and activities in sewage sludge and phosphate fertilizer-amended soil. Applied Soil Ecol., 4: 75-82. DOI: 10.1016/09291393(96)00094-7

Mendham, D.S., K.V. Sankaran, A.M. O'Connell and T.S. Grove, 2002. Eucalyptus globulus harvest residue management effects on soil carbon and microbial biomass at 1 and 5 years after plantation establishment. Soil Biol. Biochem., 34: 1903-1912. DOI: 10.1016/S0038-0717(02)00205-5

Meriles, J.M., S.V. Gil, C. Comforto, G. Figoni and E. Lovera et al., 2009. Soil microbial communities under different soybean cropping systems: Characterization of microbial population dynamics, soil microbial activity microbial biomass and fatty acid profiles. Soil Tillage Res., 103: 271-281. DOI: 10.1016/j.still.2008.10.008

Montagnini, F., B. Eibl, L. Grance, D. Maiocco and D. Nozzi, 1997. Enrichment planting in overexploited subtropical forests of the Paranaense region of Misiones, Argentina. Forest Ecol. Manage., 99: 237246. DOI: $10.1016 / \mathrm{S} 0378-1127(97) 00209-0$

Moussa, H.R. and S.M. Abdel-Aziz, 2008. Comparative response of drought tolerant and drough sensitive maize genotypes to water stress. Australian J. Crop Sci., 1: 31-36.

Otsamo, R., 1998. Effect of nurse tree species on early growth of Anisoptera marginata Korth. (Dipterocarpaceae) on an Imperata cylindrica (L.) Beauv. grassland site in South Kalimantan, Indonesia. Forest Ecol. Manage., 105: 303-311. DOI: 10.1016/S0378-1127(97)00298-3

Otsamo, R., G. Adjers, T.S. Hadi, J. Kuusipalo and A. Otsamo, 1996. Early performance of 12 shade tolerant tree species interplanted with Paraserianthes falcataria on Imperata cylindrica grassland. J. Tropical Forest Sci., 8: 381-394.

Paradelo, R. and M.T. Barral, 2009. Effect of moisture and disaggregation on the microbial activity in soil. Soil Tillage Res., 104: 317-319. DOI: 10.1016/j.still.2009.02.010

Peacock, A.D., S.J. Macnaughton, J.M. Cantu, V.H. Dale and D.C. White, 2001. Soil microbial biomass and community composition along an anthropogenic disturbance gradient within a long-leaf pine habitat. Ecol. Indicat., 1: 113-121. DOI: 10.1016/S1470160X(01)00013-9 
Saga, B.T., O.H. Ahmed, A.S. Jamaluddin, H. AbdulHamid and S. Jusop et al., 2010. Selected soil morphological, mineralogical and sesquioxide properties of rehabilitated and secondary forests. Am. J. Environ. Sci., 6: 389-394. DOI: 10.3844/ajessp.2010.389.394

Sanchez-Monedero, M.A., C. Mondini, M.L. Cayuela, A. Roig and M. Contin, 2008. Fluorescein diacetate hydrolysis, respiration, respiration and microbial biomass in freshly amended soils. Biol. Fert. Soils, 44: 885-890. DOI: $10.1007 / \mathrm{s} 00374-007-0263-1$

Saswati, M. and C.J. Vadakepuram, 2010. Influence of leaf litter types on microbial functions and nutrient status of soil: Ecological suitability of forest trees for afforestation in tropical in tropical laterite wastelands. Soil Biol. Biochem., 42: 2306-2315. DOI: 10.1016/j.soilbio.2010.09.007

Singh, N., K. Harvati, J.J. Hublin and C.P. Klingenberg, 2012. Morphological evolution through integration: A quantitative study of cranialintegration in Homo, Pan, Gorilla and Pongo. J. Hum. Evolut., 62: 155164. DOI: $10.1016 / j$ jhevol.2011.11.006

Sleytr, K., A. Tietz, G. Langergraber and R. Haberl, 2007. Investigation of bacterial removal during the filtration process in constructed wetlands. Sci. Total Environ., 380 : $173-180 . \quad$ DOI: 10.1016./j.scitotenv.2007.03.001

Susyan, E.A., S. Wirth, N.D. Anayeva and E.V. Stolnikova, 2011. Forest succession on abandoned arable soils in European Russia-impacts on microbial biomass fungal-bacteria ratio and basal $\mathrm{CO}_{2}$ respiration activity. Eur. J. Soil Biol., 47: 169174. DOI: $10.1016 /$ j.ejsobi.2011.04.002
Tang, J., Y. Mo, J. Zhang and R. Zhang, 2011. Influence of biological aggregating agents with microbial on soil aggregate stability. Applied Soil Ecol., 47: 153159. DOI: $10.1016 /$ j.apsoil.2011.01.001

Vance, E.D., P.C. Brookes and D.S. Jenkinson, 1987. An extraction method for measuring soil microbial biomass C. Soil Biol. Biochem., 19: 703-707. DOI: 10.1016/J.APSOIL.2006.06.005

Vasquez-Murrieta, M.S., B. Govarts and L. Denddoven, 2007. Microbial biomass $C$ measurements in soil of the central highlands of Mexico. Applied Soil Ecol., 35: 432-440. DOI: 10.1016/0038-0717(87)90052-6

Witt, H., W. Luck, H.C. Hennies, M. Claben and A. Kage et al., 2000. Mutations in the gene encoding the serine protease inhibitor, Kazal type 1 are associated with chronic pancreatitis. Nature Genet., 25: 213-216. DOI: $10.1038 / 76088$

Xiao, T., X.C. Scott and K. Richard, 2005. Effects of soil compaction and forest floor removal on soil microbial properties and $\mathrm{N}$ transformations in a boreal forest long-term soil productivity study. Forest Ecol. Manage., 217: 158-170. DOI: 10.1016/j.foreco.2005.05.061

Zaidi, S.K., D.W. Young, M.A. Montecino, J.B. Lian and A.J.V. Wijnen et al., 2010. Mitotic bookmarking of genes: A novel dimension to epigenetic control. Nat. Rev. Genet., 11: 583-589. DOI: $10.1038 / \mathrm{nrg} 2827$ 